Research Article

\title{
Land Improvement Solutions: Afforestation and Planting Fruit Trees and Short-Term Crops after Mine Closure in Luong Son District, Hoa Binh Province, Vietnam
}

\author{
Hai X. Nguyen $(\mathbb{D}$, Hong T. Tran, Ha T. T. Pham, Anh V. T. Pham, Trang T. Phan $\mathbb{D}$, \\ and Ho N. Pham iD \\ Research Center for Environmental Monitoring and Modeling (CEMM), University of Science, Vietnam National University, \\ Hanoi, Vietnam \\ Correspondence should be addressed to Ho N. Pham; hopn2008@yahoo.com.vn
}

Received 22 November 2019; Revised 4 March 2020; Accepted 25 March 2020; Published 8 May 2020

Academic Editor: Amaresh K. Nayak

Copyright (C) 2020 Hai X. Nguyen et al. This is an open access article distributed under the Creative Commons Attribution License, which permits unrestricted use, distribution, and reproduction in any medium, provided the original work is properly cited.

\begin{abstract}
Luong Son is a district to the east gateway of Hoa Binh province, adjacent to Hanoi the capital and the northwest of Vietnam. Against the background of the rapidly expanding natural resources exploitation, a lack of experience in the general management of resources is obvious. The problem of serious environmental pollution occurs due to the increase of mining activities. This is especially true in mining areas located near fast-growing urban areas. In particular, after the end of the exploitation and mine closure, there is a need to improve and recover the environmental conditions in order to protect untapped mineral reserves and to keep the exploitation site in a sustainable status. This includes questions of environmental safety and soil recovery within the affected areas. This article deals with 2 types of land improvement and restoration in Luong Son district: (1) designing a method for land improvement by afforestation and (2) designing a method for land improvement by planting fruit trees and short-term crops.
\end{abstract}

\section{Introduction}

Luong Son is a district to the east gateway of Hoa Binh province, being the focal point for economic and culturalsocial exchange between the Northwest Mountains and Red River Delta region (including Hanoi capital). Natural resources and labor force are abundantly available. The total natural area of the district is $36,488.85$ hectares, divided into 20 administrative units with 3 ethnic groups, mainly Muong. Although natural resources exploitation is rapidly expanding with various types of mining and processing activities, there is a lack of experience in general management $[1,2]$. The problem of serious environmental pollution occurs due to the increase of mining activities. Mining processes cause negative impacts on the environment both during operations and after mine closure. Typical negative effects are landscape change, soil degradation, and loss of biodiversity, as well the pollution of air and water. Conflicts of land use usually occur as a result of soil degradation.

This is especially true in mining areas located near fastgrowing urban areas. In such areas, the construction industry has an increasing demand for construction materials such as stone, gravel, and sand. Hoa Binh is a neighboring upland area of Hanoi with various types of minerals extraction, having many problems in the management of environmental protection and sustainable development. This article analyzes the status of soil quality at mining areas in Luong Son district, Hoa Binh. Moreover, it provides recommendations for the environmental improvement and recovery after mine closure according to environmental protection and sustainable development directions. Finally, proposals are offered for the design of environmental improvement and recovery measures for specific types of mines, using the above-mentioned recommendations. 


\section{Materials and Methods}

\subsection{Materials}

Sampling Sites. A total of 24 soil samples at 6 mines in 5 communes, Luong Son district, Hoa Binh province, were included in our sampling sites [3]. There are 4 sites with 24 samples illustrated in Table 1.

The soil sampling sites at the 6 mines are listed as follows:

(i) Construction materials mines (limestone mine) of Hop Tien Company Ltd. Trade-Building and Transportation, Seu mountain, Cao Duong commune, Luong Son district, Hoa Binh province

(ii) Construction materials mines (basalt mine) of Quang Long Construction and Trade Company Limited, Voi mountain, Hoa Son commune, Luong Son district, Hoa Binh province

(iii) Construction materials mines (limestone mine) of Trung Son commune, Luong Son district, Hoa Binh province

(iv) Production and mining area of clay mine, Da River Joint Stock Company, Hoa Son commune, Luong Son district, Hoa Binh province

(v) Production and mining area of construction materials mines (clay mine), Khai Hung Production and Trade Joint Stock Company, Tan Vinh commune, Luong Son district, Hoa Binh province

(vi) Production and mining area of limestone mine, Artillery Command, Thanh Lap commune, Luong Son district, Hoa Binh province

Some pictures of sampling sites are shown in Figures 1-6.

Analyzed Indicators. We analyzed 29 indicators, including density, bulk density, soil moisture, OM (organic master), mechanical composition, soil porosity, sustainable aggregate in water, $\mathrm{pH}_{\mathrm{H} 2 \mathrm{O}}, \mathrm{pH}_{\mathrm{KCl}}$, total $\mathrm{N}, \mathrm{P}_{2} \mathrm{O}_{5}, \mathrm{~K}_{2} \mathrm{O}$, available $\mathrm{P}_{2} \mathrm{O}_{5}$, available $\mathrm{K}_{2} \mathrm{O}, \mathrm{Ca}^{2+}, \mathrm{Mg}^{2+}, \mathrm{Na}^{+}, \mathrm{Fe}^{3+}, \mathrm{Al}^{3+}, \mathrm{Pb}, \mathrm{Cd}, \mathrm{Hg}, \mathrm{As}$, $\mathrm{Cu}, \mathrm{Zn}, \mathrm{Cr}, \mathrm{Mn}, \mathrm{CEC}$ (cation exchange capacity), and BS (base saturation).

Data and Documents. We used the environmental impact assessment report and the soil quality monitoring report of 6 mines in 5 communes, Luong Son district, Hoa Binh province [3].

\subsection{Methods}

Inheritable Method. We collected documents and results of related scientific research.

Field Survey Method. We investigated and collected information about soil and plant properties.

Rapid Assessment Method. We used expert experience during survey and research.

Soil Sampling Method. We selected soil samples for analysis according to FAO guidelines and Vietnamese standards, TCVN 5297:1995, TCVN 7538-2-2005 and TCVN $4046: 1985$.

Soil Analysis Method. This was performed according to the current Vietnamese standards.

Expert Method. We collected information; opinions of experts on soil, crop, and environment; verified and tested the credibility of documents and facts collected through other methods. We proposed reform directions, remediating the environment after mine closure.

Method of Calculating Cost of Environmental Remediation and Restoration. According to guidelines described in Appendix 11, Circular 38/2015/TT-BTNMT on environmental remediation and restoration in mineral mining activities, depending on the selected environmental remediation and restoration plan, the total estimated cost for environmental remediation and restoration $\left(M_{\mathrm{cp}}\right)$ in the research area is determined by (1) $[4,5]$.

$$
M_{\mathrm{cp}}=M_{\mathrm{kt}}+M_{\mathrm{cn}}+M_{\mathrm{bt}}+M_{\mathrm{xq}}+M_{\mathrm{hc}}+M_{\mathrm{k}} .
$$

Here,

$M_{\mathrm{kt}}$ is the cost of environmental improvement and restoration of exploited site

$M_{\mathrm{cn}}$ is the cost of environmental improvement and restoration of ground of industrial field, classified area, enrichment, supporting area, and other related activities

$M_{\mathrm{bt}}$ is the cost of environmental improvement and restoration of waste disposal site

$M_{\mathrm{xq}}$ is the cost of environmental improvement and restoration in the areas of outside border affected by exploiting activities

$M_{\mathrm{hc}}$ is the cost of maintenance of construction of environmental improvement and restoration

$M_{\mathrm{k}}$ is the other costs

The collected input data for (1) was natural conditions, including meteorological, hydrological, and socioeconomic conditions of the mineral mining area in Luong Son district, Hoa Binh province, from 2016 to 2018 [6].

\section{Results and Discussion}

3.1. Assessment of Status of Soil Quality at Mining Area in Luong Son District, Hoa Binh Province. In Luong Son district, Hoa Binh province, there are 3 specific types of construction material mines: basalt, clay, and limestone. The research team has selected 24 soil samples in 6 mines including 3 limestone mines, 2 basalt mines, and 1 clay mine in 5 communes, Luong Son district, Hoa Binh province, at site mining, production, and areas directly affected such as living quarters, warehouse, neighboring ecology, being the representative positions for assessing the quality of each mine.

Initial analysis results show that mechanical composition of soil samples mainly ranges from medium to heavy. Areas with more clay content should have good water holding capacity, with relative humidity of $40-50 \%$; high rate of water resistant 
TABLE 1: Soil sampling sites at 6 mines.

\begin{tabular}{|c|c|c|c|c|c|c|}
\hline \multirow[b]{2}{*}{ Sites } & \multicolumn{6}{|c|}{ Mark } \\
\hline & $\begin{array}{l}\text { I (limestone mine, } \\
\text { Cao Duong } \\
\text { commune) }\end{array}$ & $\begin{array}{l}\text { II (basalt mine, } \\
\text { Hoa Son } \\
\text { commune) }\end{array}$ & $\begin{array}{l}\text { III (limestone } \\
\text { mine, Trung Son } \\
\text { commune) }\end{array}$ & $\begin{array}{l}\text { IV (Clay mine, } \\
\text { Hoa Son } \\
\text { commune) }\end{array}$ & $\begin{array}{l}\text { V (Clay mine, } \\
\text { Tan Vinh } \\
\text { commune) }\end{array}$ & $\begin{array}{l}\text { VI (limestone mine, } \\
\text { Thanh Lap } \\
\text { commune) }\end{array}$ \\
\hline Mining site & D11 & D21 & D31 & D41 & D51 & D61 \\
\hline Production & D12 & D22 & D32 & D42 & D52 & D62 \\
\hline Warehouse & D13 & $\mathrm{D} 23$ & D33 & $\mathrm{D} 43$ & D53 & D63 \\
\hline $\begin{array}{l}\text { Residential, } \\
\text { ecological }\end{array}$ & D14 & D24 & D34 & D44 & D54 & D64 \\
\hline
\end{tabular}

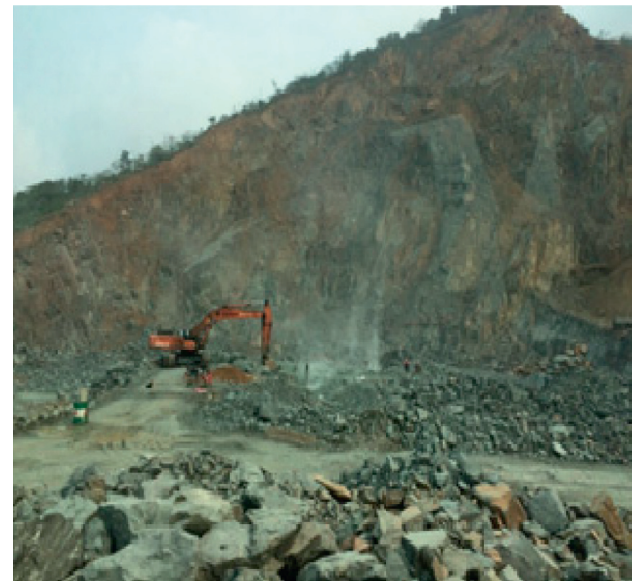

(a)

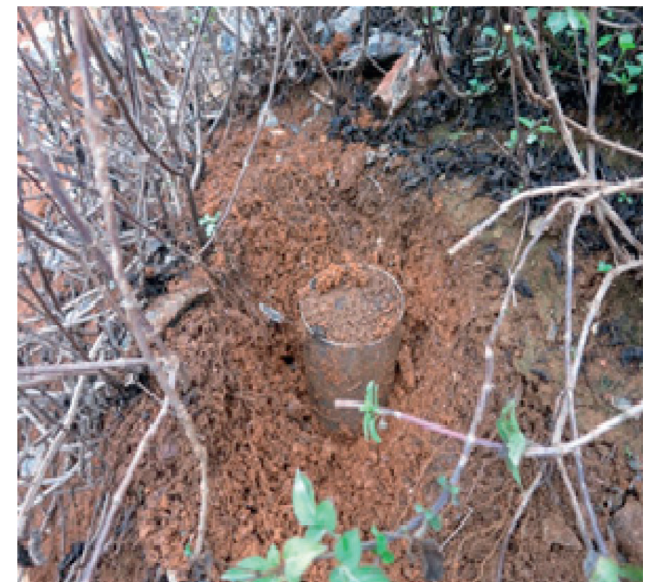

(b)

FIgURE 1: Sampling point in mining site (limestone mine).

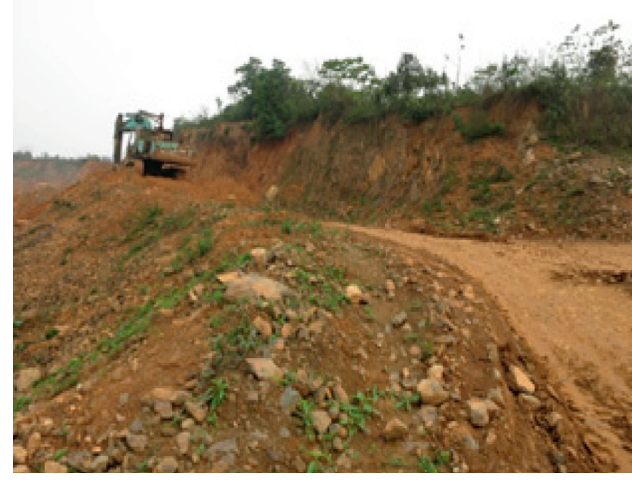

(a)

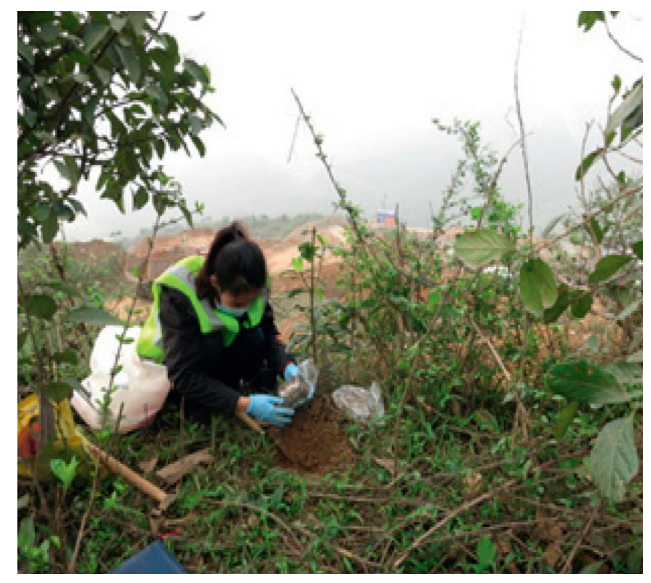

(b)

Figure 2: Sampling point in mining site (basalt mine).

aggregate; and well structured, relatively porous, airy soil. However, the clay mine area has tightly structured soil; the physical indicators of soil are suitable for crops.

Most of the soil samples have a bit below average content of total organic matter; this is a specified indicator of soil fertility, a nutrient storage for the development of plants. Cation exchange capacity (CEC) ranges from poor to medium level. The total nutrient content NPK in the soil is rather good, providing the potential source of nutrients for the crop. High levels of calcium and magnesium exchange provide nutrients for plant growth and development [7].

Heavy metals such as $\mathrm{Pb}, \mathrm{As}, \mathrm{Hg}, \mathrm{Cu}$, and $\mathrm{Zn}$ meet the standard QCVN 03 : 2008/BTNMT, and low levels of Fe and Al should not be toxic to plants.

The analysis results show that, compared with the rating scale of soil indicators of QCVN and TCVN standards, topsoil, adjacent to the mining, manufactured in 6 mines, still ensures that crops grow and develop. 


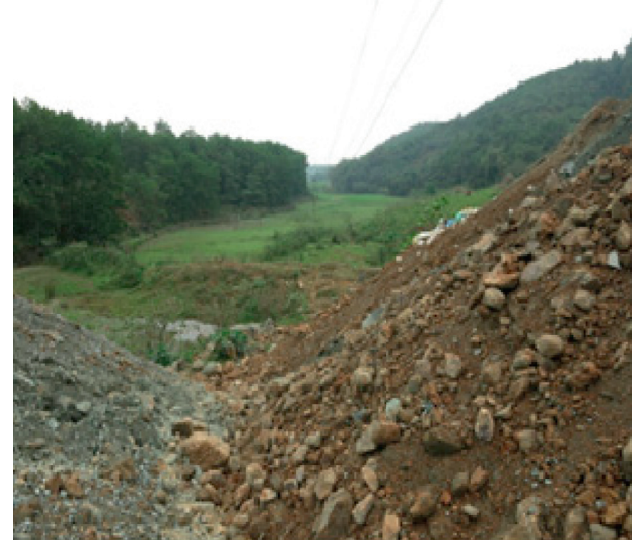

(a)

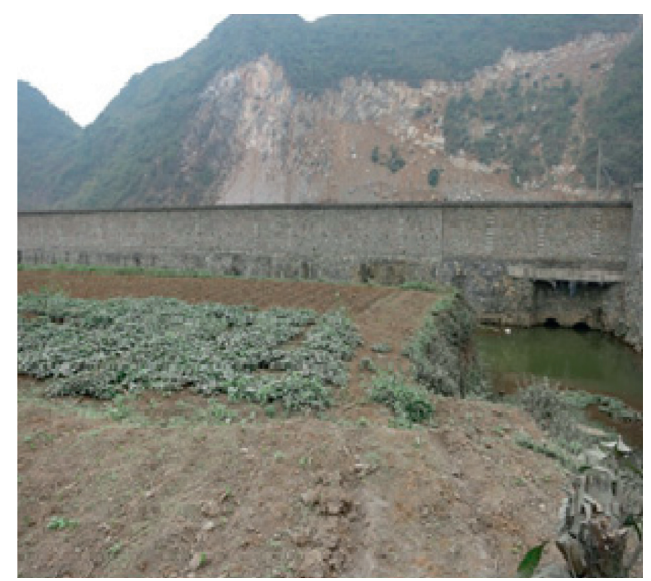

(b)

FIgURE 3: Sampling point in residential, ecological area.

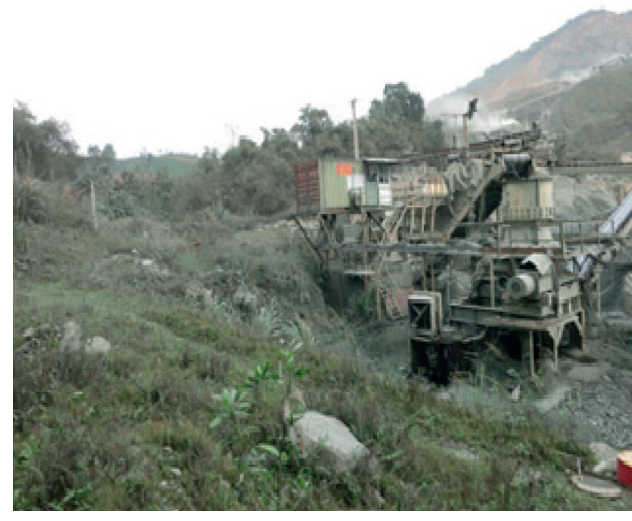

(a)

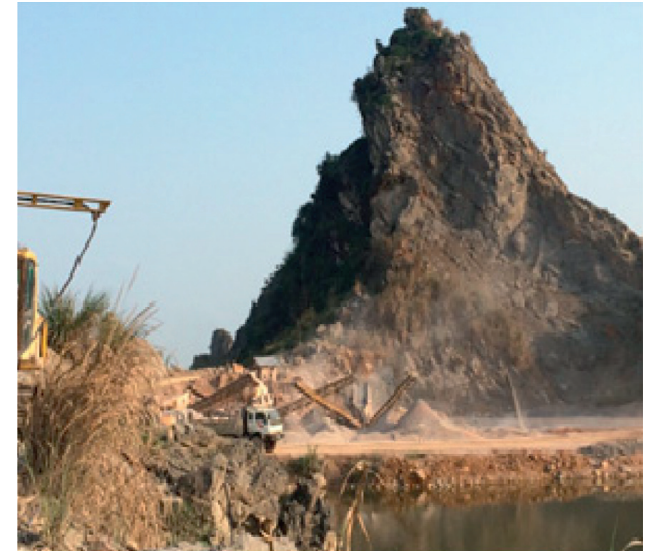

(b)

Figure 4: Sampling point in production area.

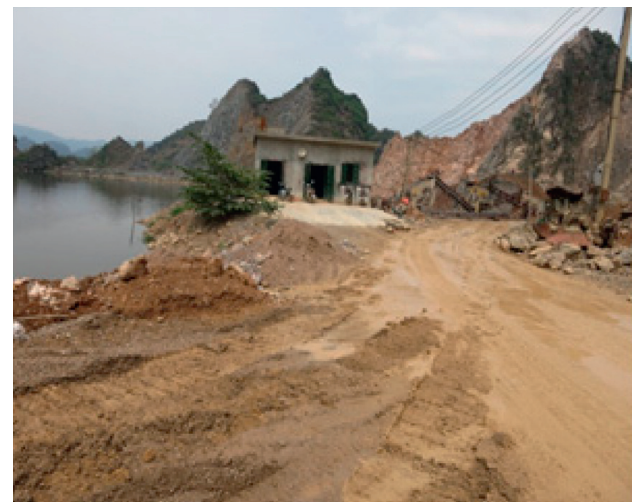

(a)

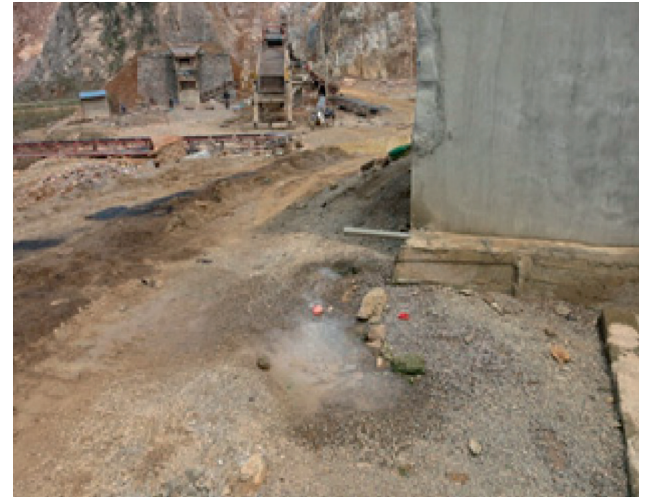

(b)

FIGURE 5: Sampling point in warehouse area (workers living place).

3.2. Selection for Environmental Improvement and Restoration in Luong Son District, Hoa Binh Province. Currently, the mining industry is applying two main methods: open-cast mining and pit mining. In almost all research areas of Luong Son district, Hoa Binh province, the exploitation technology applied is open-cast mining. The mining process has a clear impact on the environment such as deformation of geomorphology and landscape of the area. It occupies a large area of cultivation and trees to open the field, pours waste rock and soil polluting water and land around the mine, and 


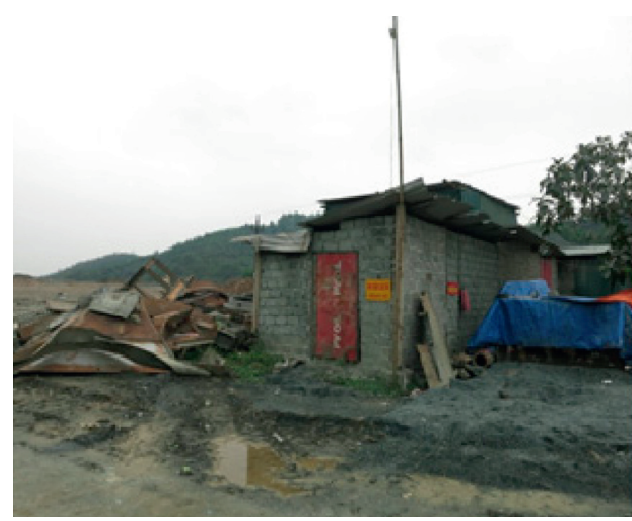

(a)

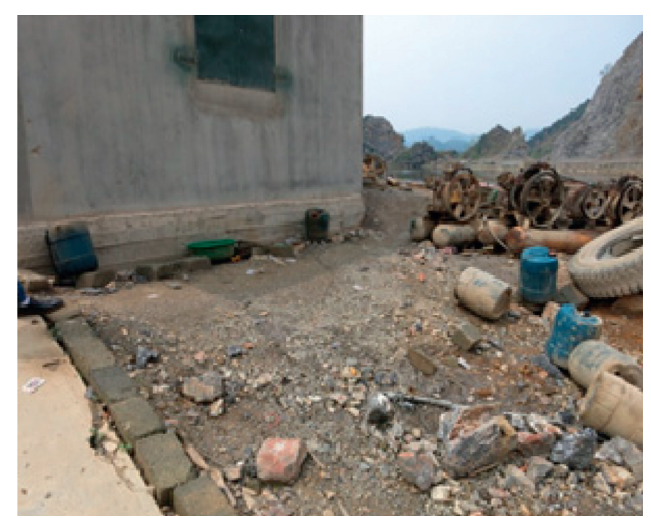

(b)

FIGURE 6: Sampling point in warehouse area (warehousing including hazardous waste).

changes the cultural and social environment both positively and negatively. The mining process usually creates terrain types of high potential for landslide and environmental pollution, endangering humans, animals, and wildlife in the affected area after mine exploitation.

Depending on specific topographic and geomorphological conditions, hydrological suitability, stability in harmony with the natural landscape of the area, financial ability of the implementing units, and land use purposes after renovation, the rehabilitation of the environment for each mine can follow different options. This may be the formation of tourist areas, new settlements, and livestock and aquaculture areas as well as areas for the restoration of vegetation and natural ecosystems. However, this article proposes 2 recommended and prioritized options having easy implementation methods, being simple to construct, and taking advantage of the land from the disposal site and stockpiles as well as the land of mined areas:

(1) To Design a Method of Soil Improvement by Forestation: This option is applied to return the mine to a state similar to the state before exploiting. This can also be applied for mines structure of weathered crust forms, having little or no huge vertical changes of the topography in the entire exploited areas and some other exploited mines.

(2) To Design a Method of Soil Improvement by Plantation of Fruit Trees and Short-Term Food Crops: This option can be applied in cases where the topography has only little vertical changes in the entire areas such as the old exploited site of clay mines structure of the weathered crust forms, the disposal sites of mine locating over the level of gravity drainage, or the soil mines which are easy to improve.

\subsection{The Main Contents of the Work of Environmental Improvement and Restoration after Mine Exploiting}

3.3.1. Plans of Land Reclamation for Environmental Restoration in Luong Son District. Environmental improvement and restoration of exploited site by filling the mining pits will firstly make the areas safer in case of the below and nearby sites still have other operators and safe for humans and animals, especially for the mines located near populated areas. This is the most effective solution in order to create favorable conditions for reimbursement or reestablishment of native ecosystems same as the states before exploiting and convert the purpose of land use to other more effective functions [7-9].

(1) The Common Tasks of Vegetational Improvement. These include the following: to plant grass and cover the slopes of the disposal sites and the edge of mines which have stopped working to prevent slope erosion from recovering woody forest gradually; to plant ranges of trees in the disposal sites and adjacent areas of the down side of operating disposal sites to reduce the destructive forces of flow, retain soils and rocks, and prevent sedimentation from harming the surrounding areas; to build dikes and alternated drainage ditches to create the favorable conditions for the growth of plants; to protect the available forests which are near the mines and disposal sites, especially the areas near the down side of disposal sites.

(2) Steps of Soil Improvement for Environmental Restoration. The solutions of environmental restoration, which were commonly applied and have effects on edge of mines and slope of disposal sites or ground of industrial field, are regenerating vegetation and greening the surface by plants. In the areas having difficult growing conditions, the plants which are easy to grow and easy to live should be planted firstly in order to gradually improve the fertility of land until it reaches the required quality, and then planting types of trees having economic efficiency can be implemented. This is the best solution to stabilize the restorable areas of environmental improvement, prevent soil erosion, contribute to regeneration of landscape, and improve environmental quality. The implemented steps include the following.

Land improvement: the rocks in exploited areas do not have sufficient nutrients for the growth of plants; thus the first step in regeneration of vegetation is conducting land improvement. 
If the rock is the bedrock, it should be filled with a layer of soil which was $20-30 \mathrm{~cm}$ of thickness when used for growing of grass, 50-70 when used for growing of industrial trees, and $70-150 \mathrm{~cm}$ when used for growing of woody plants, digging of holes, and then pouring of soil.

An extra layer of soil of $50-70 \mathrm{~cm}$ thickness was spread, and the nutritional components for the land used for agricultural purposes were tested.

The determination of agrochemical properties of waste soil and stone is the basis for determining the mode of restoration of plant seeds. Some agrochemical indicators of soil which were usually concerned are $\mathrm{pH}$, concentration of $\mathrm{P}_{2} \mathrm{O}_{5}, \mathrm{~K}_{2} \mathrm{O}$, and total nitrogen.

The process of improvement and restoration of slope surface should be conducted, respectively, at the same altitude (along the contour lines) to restrict the wash-out effect of runoff rainwater and increase the water retention of the terrain (similar to the terraces of mountainous communities).

Planting: the regeneration of vegetation could be implemented by using plant seeds having indigenous origin or from other localities. Using plant seeds having indigenous origin has the advantage of easy adaptation to the natural conditions of mines, such as soil type, climatic conditions, and evolution of ecological processes. In order to regenerate vegetation for mined areas, the following methods can be applied.

Using the plants initially nursed in potting soil. The plating methods are as follows: placing the potting tree between the hole, covering with soil and compacting root, and conducting in turn plantation from high to low level and from far to near place.

In the areas having difficult growing conditions, the plants which are easy to grow and easy to live should be planted firstly in order to gradually improve the fertility of land and until it reaches the required quality, then implement planting type of trees having economic efficient.

Fertilization: care work, irrigation, and fertilization depend on the type of trees (if necessary). Replanting the dead trees must be conducted regularly, at least in 3-5 years until the liveness and growth of $100 \%$ trees are guaranteed in order to be handed over to local or other managing units.

In the first year, care should be provided 3 times: the first period is after growing, 1-2 months. Vegetation clearance throughout the area, weeding, and clearing the grass around root width of $80 \mathrm{~cm}$ should be done. The second and third period are in October or November. Clearing the grass around root width of $1 \mathrm{~m}$ should be finished.

In the second year, care should be provided 3 times: the first period is in March or April which is the same as the first period in the first year. The work is top dressing with $200 \mathrm{~g}$ or $500 \mathrm{~g}$ micro-organic fertilizer per tree. The second and the third periods are in July-August, October-November, respectively. In these above periods, vegetation clearance throughout the area, taking care of weeding, should be completed.

In the third year, care should be provided 2 times: the first period is in March or April. Vegetation clearance, pruning bough to the height of $1.5-2 \mathrm{~m}$, should be done. Care is the same as that provided in the second year (top dressing, the grass around root width of $1 \mathrm{~m}$ ). The second period is in July or August. Cutting diseased trees and clearing the grass around the root should be done.

(3) Environmental Management and Protection in the Implementation of Environmental Improvement and Restoration. In order to manage and protect the environment, it is necessary to strengthen the propaganda of legislation on environmental protection in general and mineral activities in particular. Simultaneously enhancing the operational effectiveness and efficiency of state management agencies and having sanctions must be strong enough to handle the violations of environmental pollution caused by mineral exploiting and processing.

To adjust the provision of environmental protection, charges on environmental pollution should be considered, particularly assigning how to calculate the deposits of environmental improvement and restoration.

We should also take into account the enhancement of researchers, applications, and transfer of clean and environmental friendliness technologies in the field of mineral exploiting and processing as well as environmental restoration.

(4) Planting Techniques. These refer to alternatively planting according to the shape of crocodile fangs with the crops standard and density.

Based on the soil conditions and the level of intensive farming or erosion situation, appropriate solution is chosen for land improvement such as comprehensively ploughing; overturning soil plough; ploughing at $20-25 \mathrm{~cm}$ depth in bands plough; fertilizing when digging hole and pouring soil by mixing with fertilizer at the middle-hole depth and then covering the top with soil; implementing deep planting to ensure adequate moisture for plants; covering around the root by using straw or hay.

(5) Water Sources and Irrigation Techniques. Irrigation water sources used for trees are stored in reservoirs during the wet season, or well drilling is implemented to pour water into tank. Due to the mountainous terrain far from residential areas, the use of existing water sources should be maximized. Thus, in order to effectively use the irrigation water sources in these areas, spraying or manual form could be used to save water and ensure plants growing as well.

(6) Cost Estimate. Equation (1) is applied to estimate the cost for 2 cases in Sections 3.3.2 and 3.3.3 as illustrated in Tables 2 and 3 , respectively.

\subsubsection{Design of Methods for Improvement of Forestation} Land. The detailed plans for improvement of forestation land depend on location and terrain of each mine in Luong Son district, Hoa Binh province. However, most of the exploited mineral mines are located in hilly terrain; thus the plan that improves forestation land is considered suitable for mines with high mountainous terrain; besides, the restricted 
TABLE 2: Cost for plating 1 ha of hybridized Acacia.

\begin{tabular}{|c|c|c|c|c|}
\hline No. & Categories & Unit & Quantity & Amount before tax \\
\hline 1 & Plant seeds & Plant & 1840 & $4,600,000$ \\
\hline 2 & Afforestation & Plant & 1660 & $15,447,017$ \\
\hline \multirow[t]{5}{*}{3} & Providing care & ha & 1 & $32,253,351$ \\
\hline & Providing care in $1^{\text {st }}$ year & ha & 1 & $9,681,779$ \\
\hline & Providing care in $2^{\text {nd }}$ year & ha & 1 & $12,889,793$ \\
\hline & Providing care in $3^{\text {rd }}$ year & ha & 1 & $9,681,779$ \\
\hline & Total (1 ha) & & & $52,300,368$ \\
\hline
\end{tabular}

TABLE 3: Cost for planting longan intercropped with short-term trees.

\begin{tabular}{lcccc}
\hline No & Categories & Unit & Quantity & Amount before tax \\
\hline 1 & Plant seeds & Plant & 440 & $5,720,000$ \\
2 & Fertilizer & ha & 1 & $42,136,000$ \\
3 & Planting of fruit trees & ha & 1 & $15,225,775$ \\
4 & ha & 1 & $18,263,419$ \\
5 & Intercropping with short-term tree & ha & 1 & $33,306,680$ \\
& Providing care & & $\mathbf{1 1 4 , 6 5 1 , 8 7 4}$ \\
\hline
\end{tabular}

condition of irrigable water is also suitable for forest trees. Steps for land improvement are as follows [9].

(1) Design of Ground Leveling and Road Constructing for Planting Trees. This includes leveling the ground of exploited areas; pouring soil with $75 \mathrm{~cm}$ of average thickness; and, in the scope of leveled ground, constructing a road, with drain ditch in both sides for circulation, depending on the terrain at mines.

(2) Trees Planting and Providing Care. Types of Trees. Based on Decision No. 1422/QĐ-UBND on 13/5/2016, Decision No. 1604/QĐ-UBND on 31/8/2016, and Decision No. 07/ 2011/QĐ-UBND on 20/5/2011 by Hoa Binh Provincial People's Committee combined with consulting officials in charge of agriculture and forestry in Luong Son district, the most suitable varieties for mine closure areas are Acacia mangium, Acacia auriculiformis, and Acacia auriculiformis [10-13].

Soil Preparation. After pouring soil, a hole for planting is manually dug with the size of $0.4 \times 0.4 \times 0.4 \mathrm{~m}$; the excavated soil is poured around the crater. Hoeing in the form of crocodile's fangs to make the plants can utilize the food, well photosynthesize, and prevent erosion.

$2 / 3$ of hole is filled with small topsoil and fertilizer, with the amount of fertilizer being $0.25 \mathrm{~kg}$ NPK/hole; they are mixed with soil; and then entire hole is filled with this mixture in the form of raspberries for planting.

Planting. Tree potting is placed into the hole, the hole is backfilled, and the root is compacted. Tree is planted in turn from a high to a low level and from a far to a near place.

The hole around potting is gradually backfilled until reaching the tight state, at $1-2 \mathrm{~cm}$ higher than root collar, and then grass is used to be mulching and moisturizing for plants.

Planting Season. Spring season is from Feb to April in solar calendar. Autumn season is from Jul to Sep in solar calendar.
Planting Density. The density of planting is 1,660 trees/ ha; row $\times$ row $=3.0 \times 3.0 \mathrm{~m}$; tree $\times$ tree $=2.0 \times 2.0$.

Taking Care of Plant. The plant requires regular monitoring, care, and watering in the first year until it reaches the sustainable growth. Replanting should be done annually to replace dead or growth-incapable trees.

In the first year, care is provided 3 times: the first period is after growing for 1-2 months. Vegetation clearance throughout the area, weeding, and clearing the grass around root width of $80 \mathrm{~cm}$ should be done. The second and third period are in October or November. Clearing the grass around root width of $1 \mathrm{~m}$ should be finished.

In the second year, care is provided 3 times: the first period is in March or April which is the same as the first period in the first year. The work is top dressing with $200 \mathrm{~g}$ or $500 \mathrm{~g}$ micro-organic fertilizer per tree. The second and the third periods are in July to August and October to November, respectively. In these above periods, vegetation clearance throughout the area, taking care of weeding, should be completed.

In the third year, care is provided 2 times: the first period is in March or April. Vegetation clearance, pruning bough to the height of $1.52 \mathrm{~m}$, should be done. Care is the same as that provided in the second year (top dressing, the grass around root width of $1 \mathrm{~m}$ ). The second period is in July or August. Cutting diseased trees and clearing the grass around the root should be done.

(c) Cost Estimate (using(1)). In order to calculate the total cost of environmental rehabilitation and restoration $\left(M_{\mathrm{cp}}\right)$ for each mine, it is necessary to design and calculate the cost of environmental rehabilitation work for each mine according to the instructions in the cost summary of environmental restoration work illustrated in Appendix 11 of Circular No. 38/2015/TT-BTNMT. The legal basis for estimation of implementing cost for 1 ha of afforestation, specifically for Acacia auriculiformis and mangium, is as follows. 
(i) Based on Decision No. 1422/QĐ-UBND on May 13, 2016, and Official Letter No. 1514/UBND-XD on August 22, 2016, issued by Hoa Binh Provincial People's Committee, the price calculated for planting worker level 1 of wage is 221,242 VND, level 2 is 251,461 VND, and level 3 is 287,075 VND.

(ii) For estimating the cost of planting 1 ha of forest, specifically 1 ha of Acacia hybrid for the environmental rehabilitation and restoration plan for mines in Luong Son district, Hoa Binh province, the funding source belongs to the budget for planting trees under the guidance in Appendix 11 of Circular No. 38/2015/TT-BTNMT [10, 14, 15, 16, 17].

The calculation results of each category are shown in Table 2 .

The cost for 1 ha of afforestation in the basic constructed stage, specifically for the planting of 1 ha Acacia auriculiformis and mangium, was 52.3 million VND. This cost is paid by exploiting organizations and individuals.

3.3.3. Design of Solutions for Land Improvement to Plant Fruit and Short-Term Trees. The detailed solution for land improvement to plant fruit and short-term trees depends on the location and terrain of each mine in Luong Son district, Hoa Binh province. This solution is suitable for mines with not too high terrain, having convenient irrigation conditions; the trees have wide adaptability, standing heat and cold and suited to all types of land, such as longan. In addition, depending on the local demands, it should be combined with planting in basic constructed stage, planting legumes such as peanuts or grass to make feed for livestock. Steps of land improvement to intercrop fruit trees with annual trees are as follows.

(1) Design of Ground Leveling and Road Constructing for Planting. This includes leveling the ground of exploited areas; pouring soil with $50-70 \mathrm{~cm}$ of average thickness and then digging to pour rich soil; and, in range of leveled ground, constructing a road with drain ditch in both sides for circulation; the size of ditch depends on the terrain at mines.

(2) Tree Planting and Providing Care. Types of trees: they depend on Decision No. 57/1999/QĐ-UBND on September 3, 1999, issued by Hoa Binh Provincial People's Committee on approval of price and technical standards for some fruit trees and seeding and forest trees produced in Hoa Binh province and Decision No. 1601/QĐ-UBND on August 31, 2015, issued by Hoa Binh Provincial People's Committee on approval of the scheme for restructuring the agriculture sector toward improving value-added and sustainable development by 2020 in Hoa Binh province $[11,12,16]$.

Soil preparation: the longan is suitable for alluvial soil, light soil, and hilly soil which have $70 \mathrm{~cm}$ thick layer, $2 \%$ humus rate, and light acidity ( $\mathrm{pH} 5.5-6.5)$.

Digging holes to plant: size is $0.8 \times 0.7 \times 0.5 \mathrm{~m}$; planting distance is $5 \times 4 \mathrm{~m}$ and could be changed from 4 to $8 \mathrm{~m}$ depending on the longan seeds, land, and cultivated models. The amount of fertilizer for each hole is $30-50 \mathrm{~kg}$ animal manure, $+0.7-1 \mathrm{~kg}$ super phosphate, and $+0.2-0.3 \mathrm{~kg}$ potassium chloride. In the hill, additionally fertilizing $0.5-1 \mathrm{~kg}$ powdered lime is required. Fertilizer is mixed with topsoil before pouring into the hole.

Longan can be grown on many soils but it requires moist soil, preferably cool and rich sediment soil; hilly soil has a layer with over $70 \mathrm{~cm}$ of thickness and slope below $25^{\circ}$. When growing on hilly soil, moisturizing, plating under contour, and having band need attention to prevent erosion.

Planting: the tree is placed into the hole, and filled it with soil, the surrounding soil is compressed, and pile is plugged to clutch seeding. Then, the tree canopy is covered with straw, bean body, or hay for moisturizing, far from root by about $5-10 \mathrm{~cm}$. Moisturizing irrigation is done 1-2 times/day for the plant in the first 1-2 weeks. After 2 months, irrigation is done 1 time in 2-3 days. In the next months, irrigation could be periodically done 1 time/week.

Cleaning up the grass surrounding root should be done 4-5 times/year, combined with fertilization each time. It is possible to intercrop some legumes away from longan root in $0.8-1 \mathrm{~m}$ distance.

Planting seasons: spring season is from Mar to April in solar calendar. Autumn season is from Aug to Sep in solar calendar.

Planting density: the planting density is 400 trees/ha, row $\times$ row $=6.0 \times 6.0 \mathrm{~m}$; tree $\times$ tree $=4.0 \times 4.0 \mathrm{~m}$.

Taking care of plant: regular monitoring, providing care, and watering in the first year until the plant reaches the sustainable growth should be done. Replanting should be done annually to replace the dead trees or the trees that do not have growth ability.

Fertilization: 1 month before planting, 20-30 kg manure is mixed with $0.7 \mathrm{~kg}$ phosphorus fertilizer + grass + garbage. The crater is filled and then covered with $15-20 \mathrm{~cm}$ of topsoil. In the first 3 years, the diluted liquid fertilizer is used for irrigation.

From the $4^{\text {th }}$ year, fertilizing is annually done with $40-50 \mathrm{~kg}$ manure $+1.5 \mathrm{~kg}$ urea $+2 \mathrm{~kg}$ phosphate $+0.7 \mathrm{~kg}$ potassium, divided into 3 periods.

In the $1^{\text {st }}$ period, from Oct to Nov, fertilizing is done with $100 \%$ manure $+40 \%$ nitrogen $+40 \%$ phosphate fertilizer. In the $2^{\text {nd }}$ period, from Dec to Jan, top dressing is done to differentiate flow germ with $40 \%$ nitrogen $+30 \%$ phosphate $+40 \%$ potassium. In the $3^{\text {rd }}$ period, from Mar to April, the remaining fertilizer is used.

Pruning and shaping: the extra bough, exceeded bough, and pest bough are annually cut.

Pest prevention: these include stink bug, borer, and bat.

Intercropped plant: for intercropped plant, legumes are planted, with seed treatment before sowing.

Beds are raised with $1.2-1.5 \mathrm{~m}$ of height and $0.3-0.5 \mathrm{~m}$ of distance between 2 rows of longan, and a drainage ditch is dug. The amount of seeds calculated for 1 ha is $220-250 \mathrm{~kg}$ dried nuts (8-9\% moisture content). Planting method is using hole or divided row. Basal fertilizing and top dressing are done for 1 ha of peanut, with $4-5$ tons manure, $150 \mathrm{~kg}$ 
urea, $400-500 \mathrm{~kg}$ lime, $100-120 \mathrm{~kg} \mathrm{KCl}$, and $100-150 \mathrm{~kg}$ superphosphate.

(3) Cost Estimate (using (1)). The legal basis for estimation of implementing cost for 1 ha of fruit tree (fruit trees intercropped with short-day crops), specifically longan, $[4,5,15-18]$ is as follows.

The farmers' wage is calculated based on Decision No. 57/1999/QĐ-UBND on September 3, 1999, and Official Letter No. 1514/UBND-XD on August 22, 2016, issued by Hoa Binh Provincial People's Committee in accordance with Circular No. 05/2016/TT-BXD on March 10, 2016, issued by Ministry of Construction of Vietnam.

The cost for planting 1 ha of longan intercropped with leguminous plants as environmental rehabilitation and restoration plan for mines in Luong Son district, Hoa Binh province, is in the expenditure for planting trees under the guidance in the cost summary of environmental restoration work [4-6]. Calculation results are presented in Table 3.

The cost for planting 1 ha of fruit trees intercropped with short-term trees in basic construction stage, specifically with planting 1 ha of longan intercropped with legumes to improve land and protect the soil cover, is estimated as 114.65 million VND. This cost is paid by exploiting organizations and individuals.

\section{Conclusions}

(1) Luong Son district of Hoa Binh province has abundant natural and labor resources, with favorable geographic location, and it is also one of the focal points to promote the socioeconomic development of Hoa Binh province.

(2) The soil in former areas of mineral exploitation in Luong Son district has relatively good texture; it is tighter in clay mines, and the nutrient and heavy metal content still maintain the growth of plants.

(3) Two methods for land improvement and restoration in Luong Son district are recommended: (1) designing a method for land improvement by afforestation and (2) designing a method for land improvement by planting fruit trees and short-term crops.

(4) Designing a method for land improvement by afforestation requires ground leveling and $75 \mathrm{~cm}$ of filling soil; the plant selected is hybridized Acacia with 1660 trees/ha of density; the estimated cost for afforestation is 52.3 million VND. Designing a method for land improvement by planting fruit trees and short-term crop requires $50-70 \mathrm{~cm}$ of filling soil; plant selected is longan, intercropped with legumes (peanut); density is 400 trees/ha; estimated cost is 114.65 million VND.

\section{Data Availability}

The data for soil quality assessment are among the results of the Vietnam-Germany mission "Management of Mineral
Resource Extraction in Hoa Binh Province-A Contribution to Sustainable Development in Vietnam." Requests for access to these data will be considered by the Ministry of Science and Technology of Vietnam. The cost data used to support the estimated costs of environmental rehabilitation and restoration are specified at different regulations, decrees, and circulars issued by the government of the Socialist of Vietnam and functional agencies and are referenced in actual market. They are available from the corresponding author upon request.

\section{Conflicts of Interest}

The authors declare that there are no conflicts of interest regarding the publication of this paper.

\section{Acknowledgments}

This study was supported by the Mission of Science and Technology under the protocol program in the VietnamGermany mission "Management of Mineral Resource Extraction in Hoa Binh Province-A Contribution to Sustainable Development in Vietnam" (code: NĐT.04.GER/15).

\section{References}

[1] Electronic Portal of Luong Son District, Hoa Binh Province, http://luongson.hoabinh.gov.vn/.

[2] Electronic Portal of Luong Son District, Hoa Binh Province, http://www.hoabinh.gov.vn/.

[3] N. X. Hai, T. T. Hong, and D. T. T. Linh, "Thematic report of task "Management of mineral and resource exploitation in Hoa Binh Province-a contribution to sustainable development in Vietnam" Code: NĐT.04.GER/15, Ministry of Science and Technology, Vietnam, 2016, in Vietnamese.

[4] Circular No 38/2015/TT-BTNMT, Environmental Remediation and Restoration in Mineral Mining Activities, Ministry of Natural Resouces and Environment of Vietnam, Cầu Giấy, Vietnam, in Vietnamese, 2015.

[5] Circular No 01/2015/TT-BXD, Providing "Guidance on Determination of the Unit Labor Cost in the Management of the Construction Cost", Ministry of Construction of Vietnam, Cấu Giầy, Vietnam, in Vietnamese, 2015.

[6] P. N. Ho, “"'Report on solutions proposals for environmental remediation and restoration after mines closure", mission of Vietnam-Germany Protocol on management of mineral resource extraction in Hoa Binh province-a contribution to sustainable development in Vietnam (MAREX)," Code NĐT.04.GER/15, Ministry of Science and Technology, Cầu Giấy, Vietnam, 2018, in Vietnamese.

[7] Do Van Luan, "Assessing the effective of using land for agricultural production in Luong Son District, Hoa Binh Province,"M.S. thesis, 2015, in Vietnamese, Hanoi, Vietnam.

[8] The Management Board of Hydroelectric Project No 1, "The scheme of mine closure of quarries No. 3 in Ban Chat hydropower, Lai Chau province," in Vietnamese, 2016.

[9] H. S. Giao, B. X. Nam, V. D. Hieu, and L. N. Minh, "Exploitation of Mineral Deposits and Placer," Publisher of Science and Technology, 2015.

[10] Decision No 38/2005/QĐ-BNN, Technical and Economic Norms of Forest Plantation, Assisted Natural Regeneration and Forest Protection", Ministry of Agriculture and Rural 
Development of Vietnam, Cầu Giấy, Vietnam, in Vietnamese, 2005.

[11] Circular No 69/2011/TT-BNNPTNT, Technical and Extent Norms of Forest Plantation, Assisted Natural Regeneration and Forest Protection, Ministry of Agriculture and Rural Development of Vietnam, Câu Giấy, Vietnam, in Vietnamese, 2011.

[12] Circular No 24/2013/TT-BNNPTNT, Provisions on Replacement Afforestation upon Conversion of Forest Use Purpose to Other Purposes, Ministry of Agriculture and Rural Development of Vietnam, Cầu Giấy, Vietnam, in Vietnamese, 2013.

[13] Joint Circular No. 80/2013/TTLT-BTC-BNN, Guidelines on the Regime of Management and Use of Non-business Expenditure Source for Forest Protection and Development, Ministry of Finance of Vietnam and Ministry of Agriculture and Rural Development of Vietnam, Cầu Giấy, Vietnam, in Vietnamese, 2013.

[14] Vietnam Academy of Agricultural Sciences, The Norms of Cultivation and Plant Protection Field, Vietnam Academy of Agricultural Sciences, Ha Noi, Vietnam, in Vietnamese, 2011.

[15] The National Assembly of the Socialist of Vietnam, "mineral law No. 60/2010/QH12," dated November 17, 2010, in Vietnamese.

[16] Decree No 19/2015/NĐ-CP, 2015, Detailing the Implementation of a Number of Articles of the Law on Environmental Protection, the Government of the Socialist of Vietnam, 2015, in Vietnamese.

[17] Decree No 15/2012/NĐ-CP Dated November 29, 2012, "Stipulation in Detail the Implementation of Some Articles of the Mineral Law," the Government of the Socialist of Vietnam, 2012, in Vietnamese.

[18] The National Assembly of the Socialist of Vietnam, "Environmental Protection Law No. 55/2014/QH13," 2014, in Vietnamese. 